\title{
An improved analytical approach for the determination of bovine serum albumin in milk
}

\author{
Bärbel LIESKE ${ }^{\mathrm{a}}$, Alfred JANTZ ${ }^{\mathrm{b}}$, Berndt FINKE ${ }^{\mathrm{b} *}$ \\ ${ }^{a}$ Department of Food Rheology, Technical University of Berlin, Königin-Luise-Str. 22, \\ D-14195 Berlin, Germany \\ ${ }^{\mathrm{b}}$ Humana Milchunion eG, Bielefelder Str. 66, D-32049 Herford, Germany
}

Received 1 October 2004 - Accepted 2 March 2005

\begin{abstract}
The content of bovine serum albumin (BSA) in milk is considered as a marker of the mammary gland health of the cow. Based on its physico-chemical properties, BSA tends to form aggregates hindering its exact determination with the previously known colorimetric bromcresol green dye (BCG) procedure. The BCG method was improved by adjusting the milk salt buffer system for the exact determination of BSA in milk. In a parallel approach, size-exclusion chromatography was applied. It was found that the analytical availability of BSA in milk samples was best when milk samples were directly analyzed with BCG without sample treatments such as precipitation and filtration. Spiked milk samples showed a recovery of $98.8 \%(+/-1.5 \%)$ with the improved method. The revised BCG method was fast and reliable in comparison with size-exclusion chromatography, allowing an exact determination of BSA in milk. Based on the spectrometric and chromatographic results it was concluded that the partial oligomerization of BSA occurring in milk depends on different factors: $\mathrm{pH}$, ionic strength, concentration of BSA, actual immunological status and substances affiliated to it. The improved BCG method could be effectively used for the control of the mammary gland health status of cows.
\end{abstract}

\section{bovine serum albumin / bromcresol green dye method / udder's health status}

Résumé - Une approche analytique améliorée pour la détermination de la sérum-albumine dans le lait de vache. La teneur du lait en sérum-albumine (BSA) est considérée comme un indice de la santé de la glande mammaire de la vache. En raison de ses propriétés physicochimiques, la BSA a tendance à s'agréger, ce qui en empêche la détermination précise avec la méthode colorimétrique au vert de bromocrésol (BCG) actuellement connue. La méthode au BCG a été améliorée en ajustant le système tampon salin du lait en vue de la détermination exacte de la BSA dans le lait. Parallèlement, on a appliqué la chromatographie d'exclusion. La mise en évidence analytique de la BSA dans l'échantillon de lait était meilleure quand on analysait les échantillons de lait directement avec la procédure au BCG sans les avoir préalablement traités par des méthodes comme la précipitation et la filtration. Les échantillons de lait surchargés ont présenté un taux de récupération de $98,8 \%$ $(+/-1,5 \%)$ avec la méthode améliorée. La méthode au BCG améliorée s'est montrée rapide et fiable par rapport à la chromatographie d'exclusion et a permis la détermination exacte de la BSA dans le lait. On a pu conclure, sur la base des résultats spectrométriques et chromatographiques obtenus, que l'oligomérisation partielle de la BSA qui se produit dans le lait dépend de plusieurs facteurs : le $\mathrm{pH}$, la force ionique, la concentration de la BSA, le statut immunologique effectif et la présence des

* Corresponding author: berndtfinke@ aol.com

Abbreviation key: BSA = bovine serum albumin/ Ig $=$ Immunoglobulin/ BCG $=$ bromcresol green/ SEFPLC $=$ size-exclusion fast protein liquid chromatography $/ \mathrm{SCC}=$ somatic cell count $/ \mathrm{BTM}=$ bulk-tank $\mathrm{milk} / \mathrm{pI}=$ isoelectric point 
substances qui y sont liées. La méthode au BCG améliorée pourrait donner de bons résultats dans la surveillance du statut sanitaire des glandes mammaires de la vache.

sérum-albumine bovine / méthode au vert de bromocrésol / statut sanitaire de la mamelle

\section{INTRODUCTION}

Normal bovine milk contains 0.1 to $0.4 \mathrm{~g} \cdot \mathrm{L}^{-1}$ bovine serum albumin (BSA). This is 0.3 to $1.0 \%$ of the total nitrogen of milk [2]. BSA contributes to the serum protein and remains in whey after renneting or acid precipitation of milk. It is quite a large molecule $\left(66.3 \mathrm{~kg} \cdot \mathrm{mol}^{-1}\right)$ consisting of 582 amino acids of known sequence including 17 intramolecular disulfides and one free sulfhydryl group [23]. The disulfides are relatively close together in the polypeptide chain and stabilize the molecular structure in the natural BSA. The molecule is suggested to be elliptical in shape with three distinct globular domains [2]. Each of these domains possesses a differentiated balance of molecular binding forces on the surface, allowing the binding of anions (free fatty acids), cations $\left(\mathrm{Ca}^{2+}, \mathrm{Cu}^{2+}\right.$ and $\left.\mathrm{Mg}^{2+}\right)$ and interactions with bilirubin, cholesterol and a variety of hormones and pharmaceuticals. Moreover, BSA plays a major role in regulating and maintaining the osmotic pressure in the blood [21].

The biological function of BSA in milk is still unclear. It is suggested that it is of little significance [2]. Increased concentrations of BSA in milk are considered to be a marker of the mammary gland health [8]. There are also some results showing no significant correlation between the concentration of BSA and somatic cell count (SCC) [14], which is a known measurement of mammary gland health and of milk quality $[6,8-10,18]$. The noted differences in the significance of BSA may be partly explained by methodical difficulties in the correct analysis of BSA. Currently available methods for the determination of BSA include radial immunodiffusion [3, 22], isoelectric focusing and SDS-PAGE [16, 20] or SE-chromatography [13].
Recently, Bouchard et. al. [1] determined BSA colorimetrically using bromcresol green dye (BCG) to investigate effects of an endotoxin-induced mastitis. The colorimetric assay was applied in parallel with the estimation of SCC and N-acetyl- $\beta$-Dglucosamidase (NAG) activity, resulting in incredibly high estimates for BSA. The BSA assay applied was a modification of the method developed by Koupparis et al. [11] to measure the serum albumin in human blood sera. Koupparis et al. reported on an automated stopped-flow analysis of albumin with BCG and purple. Albumin and bromcresol green are allowed to bind at $\mathrm{pH} 4.2$ and absorption of the BCG-albumin complex is determined spectrophotometrically at $640 \mathrm{~nm}$. At pH 4.2, albumin acts as a cation to bind the anionic dye. Non-specific binding with some other serum proteins was minimized by keeping the reaction time in the analyzer as short as possible. The method developed showed sufficient agreement with the selective immunodiffusion assay.

Our own studies on the modified procedure and its efficiency at quantifying BSA in dairy fluids revealed a reasonably good correlation with the estimates obtained by SE-FPLC, but the absolute BSA levels were significantly higher and in agreement with those reported by Bouchard et al. [1] and by Guzmán et al. [4]. To explain those differences, better knowledge is required about the influence exerted by the inherent steps of the BCG method and by the mode of sample preparation prior to analysis, but also about effects of molecular-structural changes of BSA on the results of analysis. Therefore, this study aimed at qualifying the colorimetric method as a more efficient and reliable assay for BSA in milk and derived substrates. The methodical research was supported by chromatographic separations 
by use of SE-FPLC for judging the colorimetric results in comparison with molecular-structural data.

\section{MATERIALS AND METHODS}

\subsection{Milk and whey supply}

Fresh raw milk from the local dairy was skimmed at $1075 \times g$ for $30 \mathrm{~min}$. Rennet whey was prepared from skimmed raw milk which had been renneted by the use of $0.15 \mathrm{~g} \cdot \mathrm{L}^{-1}$ pure Chymogen (clotting activity 1:7500, Chr. Hansen, Lübeck, Germany) at pH 6.7 and $31{ }^{\circ} \mathrm{C}$. The curd was cut after $40 \mathrm{~min}$ and the rennet whey was isolated by centrifugation $(3200 \times g ; 10 \mathrm{~min})$ and/or by filtration using Whatman No. 42 filter paper.

The $\mathrm{pH} 4.6$ filtrate was prepared from skimmed raw milk using diluted $\mathrm{HCl}$ to precipitate casein at ambient temperature. The $\mathrm{pH} 4.6$ filtrate was separated by centrifugation and/or filtration using Whatman No. 42 filter paper. Natural milk serum was separated from skimmed raw milk at $20{ }^{\circ} \mathrm{C}$ by centrifuging at $50000 \times g$ for 60 min using a Sigma 3 K 30 centrifuge (Sigma Laborzentrifugen, Osterode, Germany). Pure BSA products were purchased from Sigma (Deisenhofen, Germany), Riedel-de Haen (Seelze, Germany) and Impfstoffwerk (DessauTornau, Germany). The purity was determined using three spectrophotometric procedures, UV-spectrophotometry at $280 \mathrm{~nm}$, Bio-Rad protein assay and the revised colorimetric method described here.

\subsection{Revised bromcresol green dye assay for BSA}

\subsubsection{Reagents}

\section{BCG stock solution}

(i) 0.0474 g BCG (Merck, Darmstadt, Germany) was dissolved in $2.0 \mathrm{~g} \cdot \mathrm{L}^{-1} \mathrm{NaOH}$ to $100 \mathrm{~mL}$.

(ii) $11.81 \mathrm{~g}$ succinic acid was dissolved in $500 \mathrm{~mL}$ distilled water and adjusted to $\mathrm{pH}$ 4.2 with $\mathrm{NaOH}$. (iii) Brij-35 (Merck).

The BCG stock solution was prepared by mixing 1 vol. of (i) with 3 vol. of (ii) and with (iii) to a final concentration of $0.08 \%$ Brij-35. The $\mathrm{pH}$ of this solution was adjusted to $\mathrm{pH} 4.20 \pm 0.05$ with $40 \mathrm{~g} \cdot \mathrm{L}^{-1}$ $\mathrm{NaOH}$. The BCG reagent was stored in a closed polyethylene bottle at room temperature and remained stable for at least four weeks.

\section{BSA standard}

BSA $\left(4.0 \mathrm{mg} \cdot \mathrm{mL}^{-1}\right)$ was dispersed in synthetic milk salt ultrafiltrate [7] at $\mathrm{pH}$ 6.7. The standard BSA curve was prepared daily by diluting the standard solution $\left(20^{\circ} \mathrm{C}\right)$ to $0.5,1.0,2.0$ and $3.0 \mathrm{mg} \cdot \mathrm{mL}^{-1}$. Then $0.2 \mathrm{~mL}$ of each solution was mixed with $1.0 \mathrm{~mL}$ deionized water and $1.0 \mathrm{~mL}$ BCG reagent. After 10 min the absorbance was measured at $640 \mathrm{~nm}$ against a BSA-free standard.

\subsubsection{Procedure}

Skimmed milk $(0.2 \mathrm{~mL})$ was mixed with $1.0 \mathrm{~mL}$ deionized water and $1.0 \mathrm{~mL} \mathrm{BCG}$ reagent using a tube mixer. Then the sample was centrifuged for $10 \mathrm{~min}$ at $2500 \times g$ to pellet the casein. After recording the absorbance of the supernatant at $640 \mathrm{~nm}$ against a blank (deionized water instead of milk), the actual sample concentration was determined in comparison with the standard BSA curve.

\subsubsection{Size-Exclusion Chromatography}

The examination of the reliability of the colorimetric results was carried out by sizeexclusion fast protein liquid chromatography (SE-FPLC; Pharmacia LKB, Uppsala, Sweden) connected to a variable UV-detector and a Shimadzu C-R 3A integrator. The separation was performed with a Superose 12 column HR 10/30 (Pharmacia). The column was loaded with $50 \mu \mathrm{L}$ of milk serum, $\mathrm{pH} 4.6$ filtrate, rennet whey or pure BSA diluted in elution buffer, consisting of $6.15 \mathrm{~g} \cdot \mathrm{L}^{-1} \mathrm{NaH}_{2} \mathrm{PO}_{4}$ and $8.77 \mathrm{~g} \cdot \mathrm{L}^{-1} \mathrm{NaCl}$, 
$\mathrm{pH}$ 6.9. The flow rate was $0.7 \mathrm{~mL} \cdot \mathrm{min}^{-1}$ and the proteins were detected at $280 \mathrm{~nm}$.

Molecular weight standards used to calibrate the Superose 12 column were BSA, $\alpha$-lactalbumin $(\alpha$-La), $\beta$-lactoglobulin $(\beta$-Lg) and bovine immunoglobulin $\mathrm{G}(\mathrm{IgG})$. All standards were purchased from Sigma and were diluted in elution buffer before use $\left(2 \mathrm{mg} \cdot \mathrm{mL}^{-1}\right)$.

\subsubsection{Statistical analysis}

All experiments were replicated three times and all measurements were carried out at least in duplicate. Effects resulting from studies in sample pre-treatment were statistically analyzed, using the Student's $t$-test. Differences were considered to be significant at $P<0.05$. The least-square method was used to fit the standard curve.

\section{RESULTS AND DISCUSSION}

\subsection{Studies in the reliability of the BCG method}

Bouchard et al. [1] determined BSA in milk by comparison with a standard BSA curve $\left(0\right.$ to $60 \mathrm{mg} \cdot \mathrm{mL}^{-1}$ of reconstituted skim milk). From this, the actual concentration of BSA in milk was calculated. Applying this procedure, the BSA level in milk was permanently overestimated $(P<0.05)$. The accuracy of the modified method was proven by adding various known amounts of BSA standards ( 1 to $4 \mathrm{mg} \cdot \mathrm{mL}^{-1}$ ) to different diluents including reconstituted skim milk, natural milk serum or simulated milk salt buffer according to Jenness and Koops [7]. The results of the analytical recovery are shown in Figure 1 and were substantiated further by regression analysis; the related regression equations were as follows:

Jenness and Koops-buffer: $\mathrm{g} \cdot \mathrm{L}^{-1}$ BSA = Abs. $(640 \mathrm{~nm}) \times 7.276-0.0115$ (1)

Natural milk serum: $\quad \mathrm{g} \cdot \mathrm{L}^{-1} \quad \mathrm{BSA}=$ Abs. $(640 \mathrm{~nm}) \times 9.079-0.0039(2)$
Reconstituted skim milk: $\mathrm{g} \cdot \mathrm{L}^{-1} \quad$ BSA $=$ Abs. ${ }_{(640 \mathrm{~nm})} \times 14.419-0.0811$ (3)

In all cases, the increase in absorbance of the BCG / albumin complex was linear. However, the quantitative recovery of added BSA from the diluents differed significantly $(P<0.05)$ as can be concluded from the coefficients of regression. From an analytical point of view it was concluded that the calibration of the BCG method should never be performed in dairy-based diluents, as the analytical recovery is reduced by the conditions of this assay.

The $\mathrm{pH}$ of the three diluents are on the level of the $\mathrm{pH}$ of natural milk but the effects described here also occurred at the $\mathrm{pH}$ of sour milk products (data not shown). From this, it was suggested that $\mathrm{pH}$-related effects may only play a secondary role. The different slopes in Figure 1 indicate a substrate-dependence via protein-protein interactions and in parallel a reduction of analytically reactive BSA molecules. The molecular changes reached maximum value when natural milk samples were used as diluents. The majority of raw milk samples in our study revealed different slopes of the standard BSA curve corresponding to regression coefficients between 13.8 and 15.0. A small number of the bulktank milk samples, however, showed no substrate-dependent interactions between milk proteins and added BSA. The slopes of the standard BSA curve as well as related coefficients of regression equations were similar to Jenness and Koops buffer (Graph 3 in Fig. 1 and Eq. 1), indicating that both the blank of milk and buffer met in a better way than using phosphate-buffered saline or distilled water (not shown). The samples of bulk-tank milk (BTM) were collected from a herd which had been suffering from immunodeficiency for quite a while. The pattern of SE-FPLC revealed no molecularstructural changes in added BSA, which was different from the majority of milk samples collected in the period of this study, and is a subject of discussion in section 3.3. 


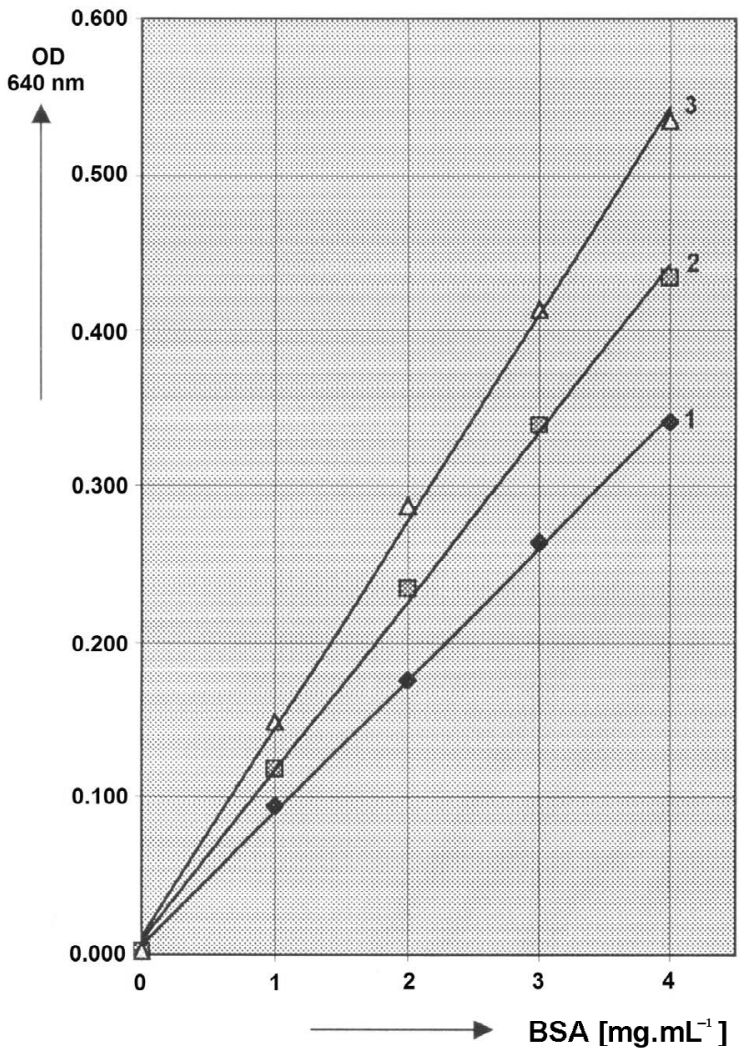

Figure 1. Plots of observed response of the BCG assay versus standard concentrations of BSA dispersed in different diluents. Graph 1, - reconstituted low-heat skim milk; Graph 2, $\square-\square$ natural milk serum (pH 6.8); Graph 3, $\triangle-\triangle$ Jenness \& Koops buffer (pH 6.8).
Taking our own findings into consideration, Jenness and Koops buffer was recommended for preparing the BSA standard curve as indicated in the methodical description of the revised BCG procedure.

Practically, absorbance is a linear function of BSA concentration from 0.1 to $4 \mathrm{mg} \cdot \mathrm{mL}^{-1}$ but it should be confirmed by suitable dilution. The total coefficients of variation calculated for two pools of dairy fluids with BSA concentrations of 1.2 to $1.6 \mathrm{mg} \cdot \mathrm{mL}^{-1}$ and 0.3 to $0.6 \mathrm{mg} \cdot \mathrm{mL}^{-1}$ were at a level of $<2.0 \%$ and $2.5 \%$, respectively.

The statistical data are based on eight BTM samples severely affected by immunodeficiency. The samples were chosen due to an exceptional long-term stability in cold storage $\left(6\right.$ to $\left.8{ }^{\circ} \mathrm{C}\right)$ allowing repeated evaluations of the revised $\mathrm{BCG}$ procedure using one BTM sample several times a week. Moreover, these milk samples were used to prove the reliability of the revised colorimetric method, as no interference with molecular interactions of BSA and other milk proteins were to be considered. The analytical recovery of added BSA (1, $1.5,2$ and $2.5 \mathrm{mg} \cdot \mathrm{mL}^{-1}$ ) in these milk samples was between 97.8 and $100.3 \%$.

\subsection{Effects of sample preparation on the quantification of BSA in milk}

The response of the colorimetric assay to pre-treatment of milk samples prior to analysis of BSA is reported in Table I. The substrates studied were skimmed raw milk (No. 1) and derived from it, $\mathrm{pH} 4.6$ filtrates 
Table I. Influence of sample preparation on the result of colorimetric BSA analysis in skimmed milk.

\begin{tabular}{lccc}
\hline No. & Substrate & Mode of preparation & BSA content $\left(\mathrm{mg} \cdot \mathrm{mL}^{-1}\right)^{\mathrm{a}}$ \\
\hline 1 & Skimmed raw milk, $\mathrm{pH} 6.7$ & without & $0.941 \pm 0.018$ \\
2 & $\mathrm{pH} 4.6$ filtrate & $36.46 \mathrm{~g} \cdot \mathrm{L}^{-1} \mathrm{HCl}, 30$ min at $50{ }^{\circ} \mathrm{C}$ & $0.941 \pm 0.020$ \\
3 & $\mathrm{pH} 4.6$ filtrate & $36.46 \mathrm{~g} \cdot \mathrm{L}^{-1} \mathrm{HCl}$ & $0.909 \pm 0.017$ \\
4 & $\mathrm{pH} 4.6$ filtrate & conc. $\mathrm{HCl}$ & $0.827 \pm 0.016$ \\
5 & Raw milk serum, $\mathrm{pH} 6.67$ & $50000 \times \mathrm{g}, 1 \mathrm{~h}$ & $0.739 \pm 0.014$ \\
6 & Rennet whey & without & $0.781 \pm 0.015$ \\
\hline
\end{tabular}

aarithmetic mean $(n=6)$.

(No. 2 to 4), natural milk serum (No. 5) and rennet whey (No. 6). As dilution effects were considered in the calculation of BSA results, the differences are related as an effect of sample pretreatment alone (Tab. I). As indicated in Table I, the analytical availability of BSA was best when milk samples were analyzed directly. Comparable results with $\mathrm{pH} 4.6$ filtrates required both the use of diluted acid for $\mathrm{pH}$ adjustment and a conditioning step for the acidified milk sample including a thermal treatment at $50{ }^{\circ} \mathrm{C}$ for 30 min while stirring (No. 2). The quantification of BSA from $\mathrm{pH} 4.6$ filtrate is still of analytical interest as it has been the preferred substrate to determine the milk serum proteins.

The sensitive properties of BSA on acidification of milk are seen in relationship to its isoelectric point (pI) which is in the range of $\mathrm{pH} 4.7$ to 4.9 [23] and thus close to the $\mathrm{pI}$ of individual caseins. During acidification BSA may precipitate partially with the casein. The extent of coprecipitation depends on the actual conditions applied for $\mathrm{pH}$ adjustment. The resulting deficits of free BSA might be significantly higher than in this study, if the acidified milk samples were centrifuged immediately after the $\mathrm{pH}$ adjustment.

The analytical availability of BSA is significantly impaired $(P<0.05)$ in milk serum (No. 5). About $21.5 \%$ of the BSA in the raw milk co-sedimented with casein micelles during centrifugation, owing to strong non- covalent binding forces between both proteins at the natural $\mathrm{pH}$ of milk. These molecular interactions were still provable when casein was clotted by chymosin (No. 6). In this study, about $17 \%$ of BSA in milk remained associated with the curd (Tab. I).

\subsection{Investigations of the biophysical properties of BSA in raw milk}

When the BCG method was calibrated with increasing concentrations of pure BSA dispersed in a dairy-based diluent, then the slope of the resulting standard curve decreased significantly (Fig. 1) over that prepared in simulated milk salt buffer. It could be concluded that some of the added BSA is analytically not available by the method applied. Possibly, this arises from the fact that BSA tends to aggregate. This fact was recently described by Militello et al. [15] and declared by the partial unfolding of the tertiary structure and by the decrease in alpha-helix and random coil contents in favor of beta-sheet aggregates.

To study this skimmed raw milk, reconstituted low-heat skim-milk and natural milk serum were spiked with BSA (1 to $\left.3 \mathrm{mg} \cdot \mathrm{mL}^{-1}\right)$. The results of spectrophotometric analysis of the four BSA products used in this study are compared in Table II. When BSA was dispersed in skimmed milk an equilibrating step was inserted to allow complete dispersion, e.g., at 25 to $30{ }^{\circ} \mathrm{C}$ for 30 min while stirring. Then the samples 
Table II. Spectrophotometric characterization of some commercial products of pure BSA (3 mg.mL $\mathrm{mL}^{-1}$ in $6.15 \mathrm{~g} \cdot \mathrm{L}^{-1} \mathrm{NaH}_{2} \mathrm{PO}_{4} / 8.77 \mathrm{~g} \cdot \mathrm{L}^{-1} \mathrm{NaCl}, \mathrm{pH} 6.9$ ) used in this study.

\begin{tabular}{|c|c|c|c|c|c|c|}
\hline \multirow[t]{2}{*}{ No. } & \multirow[t]{2}{*}{ BSA product } & \multicolumn{2}{|c|}{ UV-spectrophotometry } & \multirow{2}{*}{$\begin{array}{c}\text { BIO-Rad Assay } \\
\text { OD }_{595 n m}{ }^{b}\end{array}$} & \multicolumn{2}{|c|}{ BCG Assay } \\
\hline & & $\mathrm{A}_{280 \mathrm{~nm}}$ & $\mathrm{mg} \cdot \mathrm{mL}^{-1 \mathrm{a}}$ & & $\mathrm{OD}_{640 \mathrm{~nm}^{\mathrm{c}}}^{\mathrm{c}}$ & $\mathrm{mg} \cdot \mathrm{mL}^{-1}$ \\
\hline \multirow[t]{2}{*}{1} & Biosynth $®$ & 1.877 & 2.84 & 0.309 & 0.288 & 2.71 \\
\hline & Riedel-de Hä̈n & & & & & \\
\hline \multirow[t]{3}{*}{2} & "Dessau" & 1.980 & 3.00 & 0.325 & 0.326 & 2.96 \\
\hline & Impfstoffwerk & & & & & \\
\hline & Dessau-Tornau & & & & & \\
\hline \multirow[t]{2}{*}{3} & Lot 59 H 7612 & 1.755 & 2.66 & 0.302 & 0.281 & 2.63 \\
\hline & Sigma & & & & & \\
\hline 4 & Lot 79 H 7614 & 1.783 & 2.70 & 0.305 & 0.289 & 2.71 \\
\hline
\end{tabular}

were prepared for further chromatographic analysis by SE-FPLC to follow the molecular-structural changes in the pattern of added BSA. In SE-FPLC, the whole protein in milk is not resolved to satisfaction due to strong molecular forces between the individual caseins as well as interactions between casein and whey protein. For this reason, the milk samples were centrifuged at $50000 \times g$ for $60 \mathrm{~min}$ at $20^{\circ} \mathrm{C}$ to separate the casein fraction from serum protein at the natural $\mathrm{pH}$ of milk. The serum protein in the supernatant was diluted further in elution buffer and applied onto the column to fractionate the proteins according to their molecular size in physiological conditions. The resulting chromatographic pattern of BSA in milk serum was compared with the pattern of the pure BSA products considered next.

The pure BSA products reported in Table II were separated into two distinct fractions. The smaller one corresponded to a molecular weight of about $67 \mathrm{~kg} \cdot \mathrm{mol}^{-1}$ (16.5-min retention time) and is assigned to BSA, whereas the unknown protein separated in the second fraction of about $35 \mathrm{~kg} \cdot \mathrm{mol}^{-1}$ (18.4-min retention time) was collected from the Superose column for fur- ther analysis. The assumption that the $35 \mathrm{~kg} \cdot \mathrm{mol}^{-1}$ protein belonged to BSA was supported by two findings. First, this protein responded to the BCG reagent with a $\mathrm{A}_{280 \mathrm{~nm}} / \mathrm{OD}_{640 \mathrm{~nm}}$ coefficient of between 6.10 and 6.17 and thus on a level with the pure BSA products (Tab. II) and secondly, this protein is contained in the pattern of the natural milk serum protein as seen in Figure 2a.

The effects of adding pure BSA to a skimmed raw milk sample on the SE-chromatographic profile of the serum protein are seen in Figure 2. From that, one can conclude that increasing the BSA concentration in a natural milk sample from $0.38 \mathrm{~g} \cdot \mathrm{L}^{-1}$ (Fig. 2a) to $1.38 \mathrm{~g} \cdot \mathrm{L}^{-1}$ (Fig. 2b) leads to an increase in SEC of both the BSA signals at 16.5 and $18.4 \mathrm{~min}$ as well as the signal of the protein eluted at $11.0 \mathrm{~min}$. This phenomenon reflects the inherent molecularstructural property of BSA to build aggregates after spiking with pure BSA. If the total concentration of BSA in milk was experimentally adjusted to $2.38 \mathrm{mg} \cdot \mathrm{mL}^{-1}$ (Fig. 2c), the resulting milk serum was partially deprived of both the IgG/BSA fraction (11.0 min) and BSA (16.5 $\mathrm{min}$ and $18.5 \mathrm{~min})$, by the centrifugal forces $(50000 \times g)$, indicating 


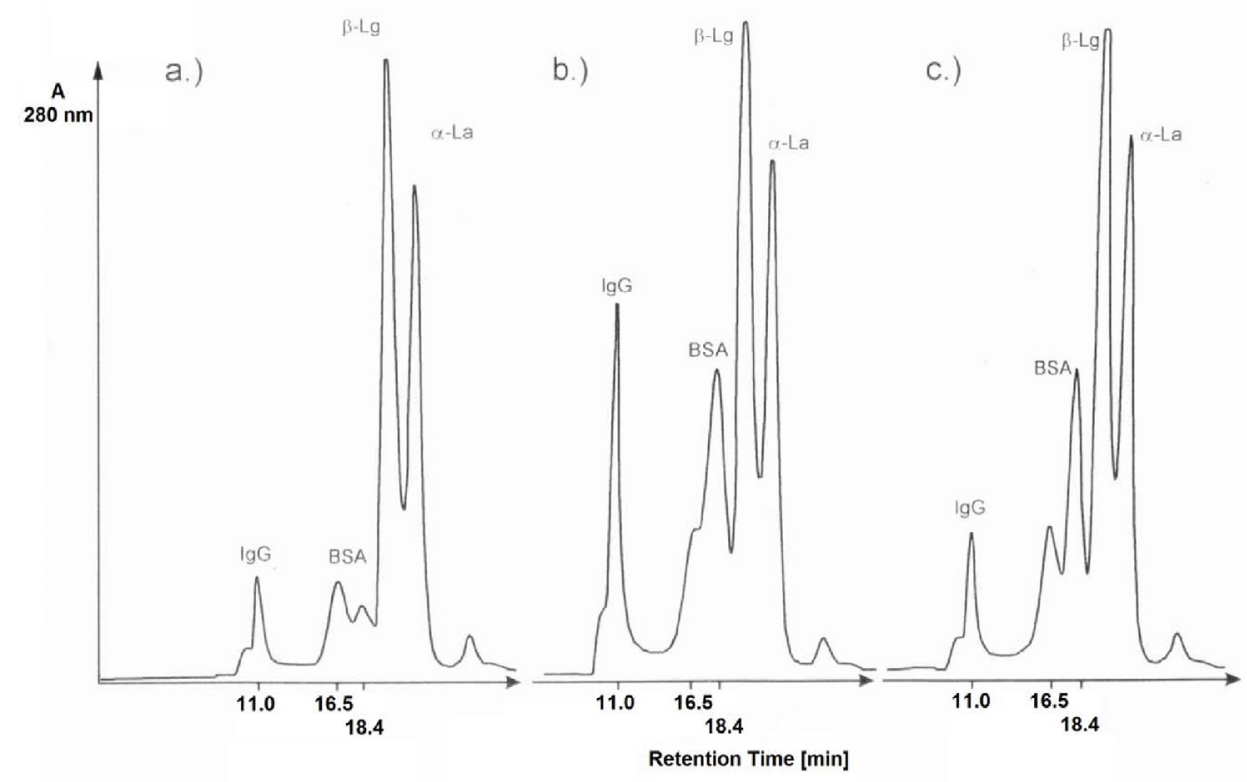

Figure 2. Effects of adding BSA to raw milk on the resulting serum patterns obtained with a SE-FPLC system, connected to a Superose 12-column. Pattern (a), normal serum. Pattern (b), plus $1 \mathrm{mg} \cdot \mathrm{mL}^{-1}$ BSA. Pattern (c), plus $2 \mathrm{mg} \cdot \mathrm{mL}^{-1}$ BSA.

a deficiency of the colloidal stability of the proteins. Precipitation of some of the added BSA with centrifugation may follow a reduced protein protection from the milk salt system, which differs markedly from the salt concentration in inflammatory udder infections. This assumption is supported by the results of the colorimetric analysis. When the concentration of BSA in the same milk sample was experimentally adjusted between $1 \mathrm{mg} \cdot \mathrm{mL}^{-1}$ and $6 \mathrm{mg} \cdot \mathrm{mL}^{-1}$ the resulting plot of BSA vs. Abs.(640nm) revealed a straight line with a regression coefficient of 14.25 (Fig. 1) indicating that proteins were completely dispersed and thus ready to react with the BCG reagent. The aggregates of BSA are also dispersed, but fail to react with the BCG reagent and undergo acid denaturation and precipitation at $\mathrm{pH} 4.2$ together with the other dairy proteins. The extent of polymerization is substrate-dependent and decreases in the following order: raw milk > reconstituted milk > natural milk serum. It seems worth mentioning that $\mathrm{BSA} / \mathrm{Ig}$ aggregates were produced spontaneously. It can be easily proved with natural milk serum spiked with BSA. The spiked sample is briefly mixed and right away separated by SEC. In the chromatographic pattern the known effects of polymerization are detectable. Undoubtedly, the spontaneous formation of aggregated BSA at ambient temperature is not implicated in covalent binding forces via disulfide bridges.

Even though in the SEC-profiles BSA aggregates eluted together with the immunoglobulins, it is not likely that BSA acts as a precursor of IgG. Both proteins differ in their amino acid sequence and their glycosylation. BSA contains no glycan chains while IgG is partly N-glycosylated, approximately $2.9 \%$ of the IgG molecule are glycans [23]. The aggregates formed by the much smaller BSA molecules were proved 
to remain stable and were not disintegrated during separation by SEC performed at $\mathrm{pH}$ 7.2 , where the natural albumin is an anion with more than 200 negative charges per molecule [21]. The molecular stability of the aggregates was also ensured when SDSPAGE with brilliant blue staining was used for characterization of BSA: two bands at approximately $67 \mathrm{~kg} \cdot \mathrm{mol}^{-1}$ and approximately $130 \mathrm{~kg} \cdot \mathrm{mol}^{-1}$ occur [5]. In SDSPAGE severe disintegrating and denaturing as well as chemical reduction of disulfides are involved with sample preparation and electrophoresis. From this, it is unlikely that the formation of BSA aggregates is a reversible reaction. These aggregates may, however, be of biological significance as they belong to the main protein in the serum pattern of milk samples collected from individual udders suffering from clinical mastitis. Such a chromatographic pattern is shown in Figure 3. The increase in blood protein in milk due to a disruption to the integrity of the mammary epithelia leads to an increase in SEC of both the BSA signals as well as the signal at the retention time of IgG/ aggregated BSA at $11.0 \mathrm{~min}$.

In addition, the new signal seen between 12.5 and $13.0 \mathrm{~min}$ belongs to the antimicrobial protein lactoferrin (Lf) (Fig. 3) as ascertained by SDS-PAGE [19].

Next, a further qualification of the $35 \mathrm{~kg} \cdot \mathrm{mol}^{-1}$ protein was necessary to rule out the existence of $\beta$ - $\mathrm{Lg}$ dimers (36 to $38 \mathrm{~kg} \cdot \mathrm{mol}^{-1}$ ). Different methods for quantifying $\beta-\mathrm{Lg}$ were used to supply proof of the assigning of the $35 \mathrm{~kg} \cdot \mathrm{mol}^{-1}$ protein. First, chromatographic analysis of $\beta-\mathrm{Lg}$ was chosen (Fig. 3). For that, the SEC column was calibrated with pure $\beta$-Lg and a standard curve was prepared. The chromatographic analysis showed $2.52 \mathrm{~g} \cdot \mathrm{L}^{-1} \beta-\mathrm{Lg}$ (SD 0.04) contained in the single fraction of $\beta$-Lg (Fig. 3). The low value appeared to be realistic due to a decreased synthesis of milk proteins involved in cases of severe mastitis and it is found to be in agreement with other chemical parameters determined in the quarter milk sample with mastitis,

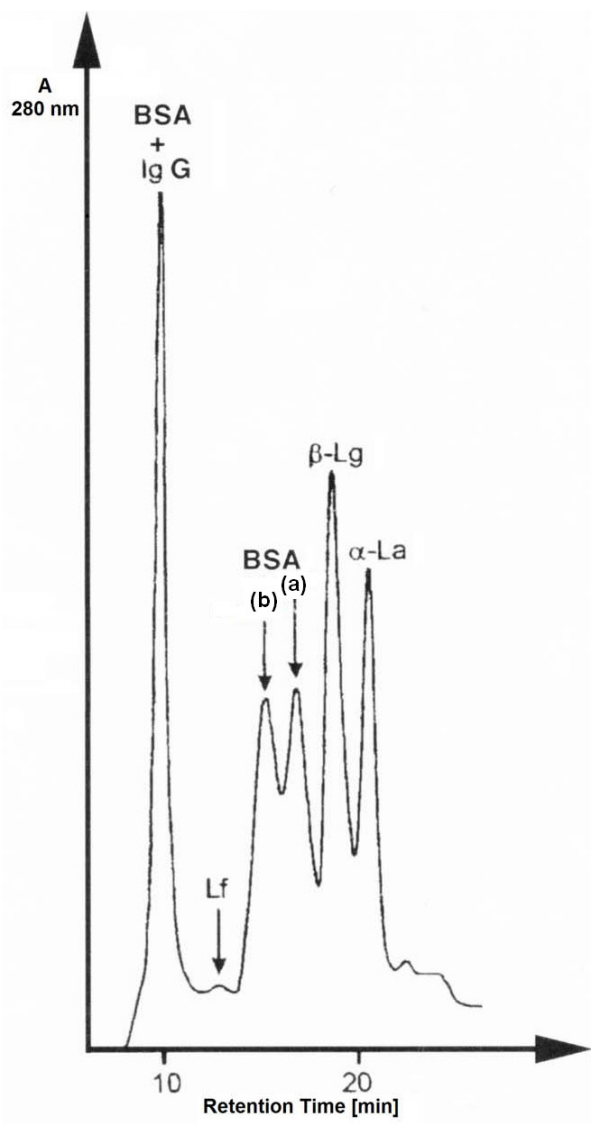

Figure 3. Effects of a clinical case of mastitis on the resulting serum pattern obtained with a SE-FPLC system and a Superose 12- column. (a): $35 \mathrm{~kg} \cdot \mathrm{mol}^{-1}$; (b): $67 \mathrm{~kg} \cdot \mathrm{mol}^{-1}$.

e.g., total protein, lactose and fat amounting to $28.6 \mathrm{~g} \cdot \mathrm{L}^{-1}$ (SD 0.03 ), $36.4 \mathrm{~g} \cdot \mathrm{L}^{-1}$ (SD $0.06)$ and $23.0 \mathrm{~g} \cdot \mathrm{L}^{-1}$ (SD 0.05), respectively.

The second method to determine applied $\beta-\mathrm{Lg}$ is a spectrophotometric assay developed for native $\beta-\mathrm{Lg}$ in raw and processed milk [12]. The spectrophotometric analysis of $\beta-\mathrm{Lg}$ in the serum of the quarter milk sample amounted to $2.55 \mathrm{~g} \cdot \mathrm{L}^{-1} \beta-\mathrm{Lg}$ (SD 0.04 ), thus agreeing with the chromatographic findings. The results of FPLC were 
further verified using SDS-PAGE [19] as a third method. If the $35 \mathrm{~kg} \cdot \mathrm{mol}^{-1}$ protein actually belonged to dimeric $\beta-\mathrm{Lg}$, then it would be checkable in the pattern of SDSPAGE. In the electrophoresis pattern (data not shown) a pale protein fraction is detectable with a molecular mass between 33 and $40 \mathrm{~kg} \cdot \mathrm{mol}^{-1}$ that may be assigned to the BSA fragment in question.

Summarizing the results obtained by the three methods, it is concluded that the apparent molecular-structural changes of natural BSA in milk collected from an udder quarter suffering from severe mastitis were confirmed. The presence of the BSA residue in the pattern of SDS-PAGE and SE-FPLC is not limited to the substrates analyzed in this study. Practically, it was contained in all sera and whey samples, in a varying concentration but at a lower percentage compared with BSA. In the literature, the allocation of the protein fraction varied a lot, and it remained mostly unconsidered.

Finally, we focus our attention once again on the restricted number of bulk-tank milk samples (BTM) being remarkable for their analytical characteristics in the BCG assay. When these samples were mixed with added BSA, then in SEC both BSA fractions $\left(67 \mathrm{~kg} \cdot \mathrm{mol}^{-1}\right.$ and $\left.35 \mathrm{~kg} \cdot \mathrm{mol}^{-1}\right)$ were increased; however, no BSA aggregates were produced. The serum protein pattern differed significantly from those of the majority of about two hundred BTM samples and were analyzed with regard to both the concentration of $\operatorname{IgG}\left(<0.25 \mathrm{~g} \cdot \mathrm{kg}^{-1}\right.$ BTM ) and BSA (> $\left.1.50 \mathrm{~g} \cdot \mathrm{kg}^{-1} \mathrm{BTM}\right)$. In comparison, the approximate average quantities of Ig and BSA in milk are $0.75 \mathrm{~g} \cdot \mathrm{kg}^{-1}$ and $0.40 \mathrm{~g} \cdot \mathrm{kg}^{-1}$, respectively [23].

From this it was suggested that the formation of aggregated BSA complexes in milk may be dependent on the presence of Ig, and thus are based on protein-protein interactions between BSA and Ig. These interactions were at the maximum in raw milk and decreased in parallel with the depletion of $\mathrm{Ig}$ with thermal treatments or with the different procedures of separation applied, and are found to be in good agreement with the colorimetric results reported in Figure 1. Comparable interactions between IgG and the much smaller plasma albumin are well known in immunochemistry. The course of this reaction goes on voluntarily, depending on entropy, and is for the most part irreversible [5, 17]. It is applicable to the results reported here. Recently, it was confirmed that antigenic determinants of bovine serum albumin were bound to $\mathrm{IgG}$ and $\operatorname{IgA}$ antibodies [5]. The reactions involved are part of the natural defence system against udder infections [22]. In this study, some BTM samples served as an example of when the natural antibody responsiveness is affected and is thus ineffective.

The BTM samples in question being deficient in Ig and without any provable reaction to added BSA were traced back to a weakened immune system on the herd level owing to toxic residues in fodder that had been improperly processed and fed to them for months. A safe one replaced this fodder and the BTM was analyzed again 13 weeks later to examine the effects of adapting the new fodder resource. The profiles of SEC (not shown) revealed a decrease in BSA and in parallel an increase in the concentration of Ig, indicating an improvement of the immune system. Moreover, some aggregated BSA/Ig was detected again when this milk was spiked with BSA. From this, it can be concluded that the status of the immune system plays the decisive role in the formation of polymerized protein in milk.

\section{CONCLUSION}

The methodical insufficiencies of quantifying BSA in milk reported during sample preparation prior to analysis or with calibration of the colorimetric method were attributable to the outstanding molecularstructural and inherent biological properties of this serum protein. 
The evaluation of reliability of the BCG method is becoming an analytical problem with normal milk samples due to incomplete recovery of the BSA added. Whenever a raw milk sample is spiked with BSA, some BSA molecules will polymerize with the natural Ig contained in milk. The aggregates of BSA and Ig are, in all probability, part of the immune reactions happening in the udder. It was confirmed by experiments studying the character of the molecular bonds stabilizing the aggregates, revealing that these bonds are produced spontaneously based on non-covalent binding forces. As seen in the chromatographic pattern the formation of the polymer structures in milk is detectable both in vitro and in vivo, in experimental spiking with BSA and in infectious udder diseases, respectively.

The proof of reliability of the revised BCG method was feasible with milk collected from udders with an acute immunodeficiency. In the chromatographic pattern of these milk samples no or minimal indication of Ig was seen. When these milk samples were spiked with increasing concentrations of BSA, the analytical recovery of BSA by the BCG method was $98.8 \pm$ $1.5 \%$ because no BSA/Ig aggregates were formed.

The biological function of BSA is defined by the differences ascertained between the two opposite milk samples with added BSA. From this it was concluded that complexed BSA/Ig is one link in the chain of immune defence reactions at an early stage of udder infection. That natural defence system, however, is switched off by toxic substances in the fodder and thus it was not surprising that relevant changes in the raw milk are not subjected to the control system of a dairy. From an interdisciplinary view it is of great interest to get reliable information about the actual immune status of one cow or on the herd level. The methodical approach of BSA analysis presented here may be used as a basis for a rapid screening test of the immune status of lactating cows. An indication of the actual status of the immune system may be obtained if milk samples are used for calibration in parallel to the working method as recommended here. The colorimetric results are confirmed further by SE-FPLC requiring two runs per sample, with and without added BSA.

Moreover, the use of BSA as an indicator of the udder health status is very promising as BSA levels in milk were correlated with SCC [1]. Giesecke and Viljoen [3] developed a radial immunodiffusion technique for quantifying BSA in milk. However, the tedious setting-up time and the measurement of the precipitin ring size, together with the 18 to $20 \mathrm{~h}$ incubation period, excluded it from large-scale monitoring programs [9].

All of the methodical insufficiencies of determining BSA in milk were overcome using the revised BCG procedure. Moreover, the BCG method is easy to perform, fast and reliable and may be carried out in a continuous analyzer with some significant advantages if large numbers of samples were to be analyzed.

Acknowledgments: The authors would like to acknowledge C. Falke, A. Kadow, S. Graf and S. Jung for their contribution to the experimental work.

\section{REFERENCES}

[1] Bouchard L.S., Blais C., Desrosiers X., Zhao X., Lacasse P., Nitric oxide production during endotoxin-induced mastitis in the cow, J. Dairy Sci. 82 (1999) 2574-2581.

[2] Fox P.F., McSweeney P.L.H., Dairy Chemistry and Biochemistry, Chapman and Hall, London, UK, 1998.

[3] Giesecke W.H., Viljoen M.H., The diagnosis of subclinical mastitis in lactating cows: a comparison of cytological methods and a monovalent radial immunodiffusion test, Onderstepoort J. Vet. Res. 41 (1974) 51-74.

[4] Guzmán A.A., Peréz M.D., Marquez R.M., Garza J.R., Colorimetric determination of bovine serum albumin (BSA) in milk using bromcresol green dye, J. Dairy Sci. 69 (Suppl. 1) (1986) 102. 
[5] Hilger C.F., Grigoni G., de Beaufort G., Michel J., Freilinger F., Hentges F., Different binding of $\mathrm{IgG}$ and $\mathrm{IgA}$ antibodies to antigenic determinants of bovine serum albumin, Clin. Exp. Immunol. 123 (2001) 387-394.

[6] Jayarao B.M., Wolfgang D.R., Bulk-tank milk analysis. A useful tool for improving milk quality and herd udder health, Vet. Clin. Food Anim. 19 (2003) 75-92.

[7] Jenness R., Koops J., Preparation and properties of a salt solution which simulates milk ultrafiltrate, Neth. Milk Dairy J. 16 (1962) 153-164.

[8] Kehrli J.M.E., Shuster D.E., Factors affecting milk somatic cells and their role in health of the bovine mammary gland, J. Dairy Sci. 77 (1994) 619-627.

[9] Kitchen B.J., Review of the progress of dairy science: bovine mastitis: milk compositional changes and related diagnostic test, J. Dairy Res. 48 (1981) 167-188.

[10] Kitchen B.J., Middleton G., Durward I.G., Andrews R.J., Salmon M.C., Mastitis diagnostic tests to estimate mammary gland epithelial cell damage, J. Dairy Sci. 63 (1980) 978-983.

[11] Koupparis M.A., Diamandis E.P., Malmstadt H.V., Automated stopped-flow analyser in clinical chemistry; determination of albumin with bromcresol green and purple, Clin. Chim. Acta 149 (1985) 225-235.

[12] Lieske B., Konrad G., Faber W., A new spectrophotometric assay for native and processed milk, Int. Dairy J. 7 (1997) 805-812.

[13] Lieske B., Konrad G., Faber W., Chromatographic analysis of serum protein in bulk milk. A possibility to detect changes of the mammary tissue as well as of the manufacturing properties of milk, virtual conference: Sustainable Animal Production. Forum 3: Product Safety, October 1999-April 2000 (Internet session).

[14] Lindmark-Månsson H., Svensson U., Paulsson M., Aledén G., Frank B., Johnsson
G., Influence of milk components, somatic cells and supplemental zinc on milk processability, Int. Dairy J. 10 (2000) 423-433.

[15] Militello V., Casarino C., Emanuele A., Giostra A., Pullara F., Leone M., Aggregation kinetics of bovine serum albumin studied by FTIR spectroscopy and light scattering, Biophys. Chem. 107 (2004) 175-187.

[16] Murphy M.C., Howell N.K., Effect of the attachment of valine residues on the physicochemical and functional properties of bovine serum albumin, J. Sci. Food Agric. 54 (1991) $245-253$

[17] Rappoport S.M., Medizinische Biochemie. 5. Aufl., VEB Verlag Volk und Gesundheit, Berlin, DDR, 1969, pp. 516-520.

[18] Rogers S.A., Mitchell G.E., The relationship between somatic cell count, composition and manufacturing properties of bulk milk. 6 . Cheddar cheese and skim milk yoghurt, Aust. J. Dairy Technol. 49 (1994) 70-74.

[19] Schägger H., von Jagow G., Tricine-sodium sulfate-polyacrylamide gel electrophoresis for the separation of proteins in the range from 1 to $100 \mathrm{kD}$, Anal. Biochem. 166 (1987) 368-379.

[20] Sheffield L.G., Mastitis increases growth factor messenger ribonucleic acid in bovine mammary glands, J. Dairy Sci. 80 (1997) 2020-2024.

[21] Tietz N.W., Textbook of Clinical Chemistry, W. B. Saunders Co., Philadelphia, PA, USA, 1986.

[22] Wagter L.C., Mallard B.A., Wilkie B.N., Leslie K.E., Boettcher P.J., Dekkers J.C.M., A quantitative approach to classifying Holstein cows based on antibody responsiveness and its relationship to peripartum mastitis occurrence, J. Dairy Sci. 83 (2000) 488-498.

[23] Walstra P., Jenness R., Dairy Chemistry and Physics. John Wiley \& Sons, New York, NY, USA, 1984. 